\title{
Life in the lead: extreme densities of narwhals Monodon monoceros in the offshore pack ice
}

\author{
Kristin L. Laidre ${ }^{1,2, *}$, Mads Peter Heide-Jørgensen ${ }^{2}$ \\ ${ }^{1}$ Polar Science Center, Applied Physics Laboratory, University of Washington, 1013 NE 40th Street, Seattle, \\ Washington 98105-6698, USA \\ ${ }^{2}$ Greenland Institute of Natural Resources, c/o Greenland Representation, Strandgade 91, 3, Postboks 2151, \\ 1016 Copenhagen K, Denmark
}

\begin{abstract}
There is a paucity of information on abundance, densities, and habitat selection of narwhals Monodon monoceros in the offshore pack ice of Baffin Bay, West Greenland, despite the critical importance of winter foraging regions and considerable sea ice declines in the past decades. We conducted a double-platform visual aerial survey over a narwhal wintering ground to obtain pack ice densities and develop the first fully corrected abundance estimate using point conditional markrecapture distance sampling. Continuous video recording and digital images taken along the trackline allowed for in situ quantification of winter narwhal habitat and for the estimation of fine-scale narwhal habitat selection and habitat-specific sighting probabilities. Abundance at the surface was estimated at 3484 (coefficient of variation $[\mathrm{CV}]=0.46$ ) including whales missed by observers. The fully corrected abundance of narwhals was 18044 (CV =0.46), or approximately one-quarter of the entire Baffin Bay population. The narwhal wintering ground surveyed $\left(\sim 9500 \mathrm{~km}^{2}\right)$ had 2.4 to $3.2 \%$ open water based on estimates from satellite imagery (NASA Moderate Resolution Imaging Spectroradiometer) and 1565 digital photographic images collected on the trackline. Thus, the $\sim 18000$ narwhals had access to $233 \mathrm{~km}^{2}$ of open water, resulting in an average density of $\sim 77$ narwhals $\mathrm{km}^{-2}$ open water. Narwhal sighting probability near habitats with $<10 \%$ or 10 to $50 \%$ open water was significantly higher than sighting probability in habitats with $>50 \%$ open water, suggesting narwhals select optimal foraging areas in dense pack ice regardless of open water availability. This study provides the first quantitative ecological data on densities and habitat selection of narwhals in pack ice foraging regions that are rapidly being altered with climate change.
\end{abstract}

KEY WORDS: Abundance $\cdot$ Density $\cdot$ Greenland $\cdot$ Narwhal $\cdot$ Pack ice $\cdot$ Site fidelity Resale or republication not permitted without written consent of the publisher

\section{INTRODUCTION}

Feasible and robust methods for monitoring population distributions, abundances and densities are critical for understanding the effects of climate change on highly adapted polar marine mammals. Population parameters must also be linked with real-time quantitative habitat metrics so that concurrent changes in habitat availability and habitat selection can be evaluated. During the last several decades large-scale environmental changes have occurred in the Baffin Bay ecosystem, including a marked annual decline in sea ice extent (9 to $11 \%$ decline per decade since 1979 ;
Perovich \& Richter-Menge 2009) and earlier sea ice break-up date (Stirling \& Parkinson 2006). Ocean temperatures in West Greenland have also warmed since the mid-1990s at all depths (Zweng \& Münchow 2006), with an especially prominent increase in temperature beginning in 2000 (Laidre et al. 2009, 2010).

The narwhal Monodon monoceros, an Arctic cetacean that lives in one of the most seasonally dynamic environments on the planet, displays high seasonal fidelity to relatively small foraging regions in the offshore pack ice. The majority of narwhals worldwide aggregate in the dense winter pack ice in Baffin Bay and Davis Strait between November and April (Innes 
et al. 2002, Heide-Jørgensen et al. 2010, Richard et al. 2010). Narwhals often return to specific wintering grounds within this offshore region year after year (Heide-Jørgensen et al. 2003), where they make daily dives that reach depths of $>1800 \mathrm{~m}$ to feed on Greenland halibut Reinhardtius hippoglossoides, their primary prey (Laidre et al. 2003, 2004a,b). This highly specialized predation in specific wintering grounds accounts for the majority of the narwhal's annual energetic input (Laidre et al. 2004a), which suggests that the site fidelity strategy has been successful over the long term. It is, however, unclear how this strategy might fare in the face of climate change, which is having a dramatic effect on the seasonal sea ice dynamics of the narwhal's winter habitat.

Narwhal wintering grounds have been identified through satellite tracking studies (Heide-Jørgensen et al. 2003, Laidre et al. 2003, Dietz et al. 2008). Little is known about densities, abundances, or habitat selection in these offshore areas primarily because of the logistic and financial challenges of monitoring in a large, remote Arctic region. The present study is the first robust narwhal abundance estimate based on a visual aerial survey of a southern wintering ground known to be an important foraging area for subpopulations of narwhals from both Greenland and Canada (Heide-Jørgensen et al. 2002, Dietz et al. 2008). This study also quantifies narwhal sea ice habitat selection on the wintering grounds using data collected from georeferenced digital aerial photography and habitatselection indices. Finally, this study compares narwhal sea ice habitat estimates using data from 3 contrasting spatial scales and sources. Considering the logistics and expense of relying on offshore winter surveys, these are critical steps for developing optimal monitoring approaches to detect changes in habitat selection and availability (Laidre \& Heide-Jørgensen 2005a).

\section{MATERIALS AND METHODS}

Visual aerial survey. A visual aerial survey was conducted over the narwhal wintering grounds in Baffin Bay, West Greenland (between $67^{\circ}$ to $68.5^{\circ} \mathrm{N}$ and $58^{\circ}$ to $61^{\circ} \mathrm{W}$ ) on 3 April 2008 (see Fig. 1) from a DeHavilland Twin Otter DHC6 airplane equipped with a long-range fuel tank ( $7 \mathrm{~h}$ flying capability) and 4 bubble windows. The survey was conducted as a double-platform experiment with 4 independent observers, 2 at the front and 2 at the rear of the survey plane (see Heide-Jørgensen et al. 2010). Observers were audibly isolated. The distance between front and rear observers within the aircraft was approximately $4 \mathrm{~m}$ and the fuel tank and recording equipment prevented visual or verbal communication of sightings between observers.
The observers recorded whale sightings, group sizes, sea state and visibility from either side of the aircraft. A downward-looking and a forward-looking video camera (Sony HD) and a still digital camera (Canon EOS MARK 3 D1 with a $24 \mathrm{~mm}$ Canon IF ED lens) were mounted in the camera port of the plane. Digital still images were collected every $5 \mathrm{~s}$ on the trackline and video recording was continuous. Calibration images were taken of the runway in Kangerlussuaq, West Greenland, after takeoff at 3 altitudes (213, 610 and $1524 \mathrm{~m}$ [i.e. 700,2000 and $5000 \mathrm{ft}$ ]) to calibrate the field of view for the video and digital imagery.

Weather conditions on 3 April 2008 were bright sun, an air temperature of $-10^{\circ} \mathrm{C}$ and a cloud-free sky. The plane flew at a cruising altitude of $1981 \mathrm{~m}$ (6500 ft) until it reached the narwhal wintering grounds when it then flew on effort at $165 \mathrm{~km} \mathrm{~h}^{-1}\left(46 \mathrm{~m} \mathrm{~s}^{-1}\right)$ at an altitude of $213 \mathrm{~m}$ (700 ft). A series of 8 straight line transects were covered in a zigzag pattern working from the north (Transect 46) to the south (Transect 39). Points at the end of each transect where the plane turned around were off effort and were not included in the analysis. Transects were designed to cover the southern narwhal wintering grounds (Laidre et al. 2003) and to replicate a previous offshore survey conducted in 2000 in the same area (Heide-Jørgensen et al. 2002).

Sightings and a log of the cruise track from the aircraft's GPS were recorded on a 4 channel video- and audio-recording computer (sDVRms, Red Hen Systems, available at: www.redhensystems.com). Declination angle to sightings was measured by each observer with Suunto inclinometers. The declination angles $(\psi)$ recorded by the observers were converted to the perpendicular distance of the whale to the trackline $(x)$ using the following equation taken from Lerczak \& Hobbs $(1998 a, b)$ :

$x=\cos (\psi)\left[(R+v) \sin (\psi)-\sqrt{R^{2} \sin ^{2}(\psi)-2(2 R+V) \cos ^{2}(\psi)}\right]$

where $R$ is the radius of the Earth (taken to be $6370 \mathrm{~km}$ ) and $v$ is the altitude of the airplane in meters. Group size and distance were averaged across the 2 platforms. Groups of narwhals appeared as welldefined clusters in close spatial proximity that were separated by several seconds of flying while on effort.

Abundance estimate. A point conditional independence mark-recapture distance sampling estimate was developed (Laake \& Borchers 2004, Borchers et al. 2006) where duplicate sightings between the 2 survey platforms were determined using coincidence in time $(<3 \mathrm{~s})$, group size ( \pm 3 whales) and perpendicular distance $(+200 \mathrm{~m})$ to each sighting. The probability of detection on the trackline was estimated from the set of trials and duplicates and the shape of the detection function was estimated from the perpendicular dis- 
tance distribution using Distance 6.0 (Thomas et al. 2009).

A mark-recapture function was used to estimate the probability that a narwhal was detected by one observer platform given that it was detected by the other platform using the logistic form:

$$
p_{1 \mid 2}(x, z)=p_{211}(x, z)=\frac{\exp \left(\beta_{0}+\beta_{1} x+\sum_{k=1}^{K} \beta_{K+1} z_{K}\right)}{1+\exp \left(\beta_{0}+\beta_{1} x+\sum \beta_{K+1} z_{K}\right)}
$$

where $x$ is the perpendicular distance of the sighting with covariates $z, K$ is the number of covariates, subscripts 1 and 2 represent the 2 observer platforms and $\beta_{0}, \beta_{1}, \ldots, \beta_{K}$ represent the parameters to be estimated. Both half-normal and hazard rate functional forms were tested and selected based on Akaike's information criterion (AIC).

Abundance $(\hat{N})$ of narwhals in the survey area was obtained using the formula:

$$
\hat{N}=\frac{A}{2 w L} \sum_{j=1}^{\mathrm{n}} \frac{s_{j}}{\hat{p}_{j}}
$$

where $s_{j}$ is the size of group $j$ in the survey area, $w$ is the truncation distance, $L_{i}$ is the total effort in the survey area, $\mathrm{n}$ is the total number of detections in the survey area, $\hat{p}_{j}$ is the estimated probability of detecting group $j$ in the survey area and $A$ is the size of the survey area. Density of narwhals was estimated using:

$$
\hat{D}=\frac{\hat{N}}{A}
$$

and the expected group size (where $\hat{N}_{\mathrm{G}}=$ abundance of groups) in the survey area was estimated using:

$$
\hat{E}[s]=\frac{\hat{N}}{\hat{N}_{\mathrm{G}}}
$$

The abundance of narwhals at the surface was corrected for the fraction of whales submerged (i.e. diving) during the survey (availability bias) with data from time-depth recorders deployed on free-ranging narwhals in winter (cf. Heide-Jørgensen et al. 2010) using the formula:

$$
\hat{N}_{\mathrm{C}}=\frac{\hat{N}}{\hat{a}(0)}
$$

where the parameter $\hat{a}(0)$ is the estimated proportion of time whales are available for detection. The coefficient of variation $(\mathrm{CV})$ of $\hat{N}_{\mathrm{C}}$ is given by:

$$
\mathrm{CV}\left(\hat{N}_{\mathrm{C}}\right)=\sqrt{\mathrm{CV}^{2}(\hat{N})+\mathrm{CV}^{2}(\hat{a}(0))}
$$

Satellite-based sea ice habitat data. Satellite-based observations of sea ice concentration were obtained from a NASA Moderate Resolution Imaging Spectroradiometer (MODIS) image taken on 3 April 2008, the day of the survey. Surface reflectance data recorded by 3 MODIS bands between the 459 and $670 \mathrm{~nm}$ wavelengths were at a spatial resolution of $250 \mathrm{~m}$. All cells in the multispectral image were classified into 3 habitat types: (1) open water, (2) light pack ice or new ice (thin gray ice that had formed in the last 24 to $48 \mathrm{~h}$ ) or (3) medium to heavy pack ice (older ice estimated to be $>5 \mathrm{~cm}$ thick with snow cover including pressure ridges) using the Isodata clustering algorithm (ERDAS Imagine 9.2) based upon the strength of absorption and reflectance. The clustering algorithm achieved $95 \%$ confidence in assigning each $250 \mathrm{~m}$ grid cell the most similar classification of sea ice type. The area of each of the 3 classes of sea ice $\left(\mathrm{km}^{2}\right)$ in the survey region was calculated in ArcGIS 9.2 using the Spatial Analyst function.

Aerial digital sea ice habitat data. During the survey, 1565 still images of the sea surface were collected along the survey trackline at $5 \mathrm{~s}$ intervals. Digital image coverage was calibrated and each image covered a rectangular area of $261 \times 173 \mathrm{~m}\left(19053 \mathrm{~m}^{2}\right)$ and was georegistered to the survey trackline. Due to brief power outages to the digital camera while in flight, some transects did not have continuous photographic coverage. However, available images were treated as independent samples in the analysis and sea ice was estimated as average proportions for each habitat. After georegistering, the entire area in each image was digitized in ArcGIS (Editor extension) and areas were visually classified as polygons into the same 3 habitat types used in the MODIS image: (1) open water, (2) light pack ice (thin gray ice with evidence of narwhal surfacing hummocks) or (3) dense pack ice (thick ice covered with snow and ridges too thick to be broken by a narwhal). Area $\left(\mathrm{km}^{2}\right)$ of each habitat type was calculated in each photographic digital image and summarized according to transect. The total area of open water and new ice in the survey area were calculated from both the MODIS image and the sample set of photographic images along each transect, as well as all transects combined.

The continuous recordings by the downward-looking video camera along the trackline were also used to roughly estimate the segments along the trackline that were covered in sea ice. Video was analyzed frame by frame where a change to a full screen $(\sim 40 \mathrm{~m}$ resolution) of either ice or open water indicated the change of the binary classification ('ice covered' or 'open water').

The satellite-based (MODIS) and in situ-based (inflight cameras) sea ice sources provided 3 independent estimates of narwhal pack ice habitat in the surveyed region at 3 unique spatial scales. The resulting open water estimate in the survey area was contrasted for each of the 3 approaches.

Probability of narwhal sightings and habitat patch composition. The probability that a narwhal sighting would occur in the vicinity of 1 of 6 habitat patch types was estimated using the series of $n=1565$ photographic images taken along each transect and the on-effort 
sightings. These probabilities were related to habitat categories associated with the digital photographic data. Here more refined categorical sea ice habitat assignments were used to take advantage of the high resolution digital photographic sea ice images. Categorical habitats were based on varying proportions of open water, light ice, and heavy ice in the image frame. Specifically, the 6 categories were (1) $100 \%$ heavy ice with no open water, (2) mixed heavy and new ice with no open water, (3) $100 \%$ new ice with no open water, (4) $<10 \%$ open water, (5) 10 to $50 \%$ open water and (6) $>50 \%$ open water. All sightings were temporally linked to the closest image. Any sighting taken at a $>3$ s interval from an image was removed from the analysis. This occurred only in those brief periods when photographs were not taken due to unexpected power outages to the camera. Narwhal sightings did not necessarily occur within the defined bounds of each image, as the image covered an area of $19053 \mathrm{~m}^{2}(271 \times 73 \mathrm{~m})$ under the plane, while sightings were within $700 \mathrm{~m}$ of the trackline. We considered the photograph to be a sample of habitat in close proximity $(<500 \mathrm{~m})$ to narwhal occurrence.

The probability of a narwhal sighting $\left(\mathrm{P}_{i}\right)$ in each of the habitat patch types (i) and the expected group size of narwhal sightings given that a sighting occurred $\left(S_{i}\right)$ was estimated for each of the sea ice habitat types. The product of these 2 measurements yielded the expected number of narwhals per habitat type. Randomizations were used to test whether the differences between habitat types were greater than expected by random sampling. These tests were performed by randomizing the sightings along the transect and reassociating them with habitat categories. This procedure was repeated 10000 times and the number of sightings with lower or higher values of $\mathrm{P}\left(S_{i}\right)$ and $\mathrm{E}\left(\mathrm{N}_{i} \mid S_{i}\right)$ were counted to obtain p-values. This method was selected as it makes minimal assumptions and gives asymptotically exact $\mathrm{p}$ values. All analyses were performed using the R software package (R Development Core Team 2009).

\section{RESULTS}

\section{Distribution and abundance of narwhals}

A total of 57 narwhal sightings were obtained within the transect width ( 0 to $700 \mathrm{~m}$ ) and used for the abundance estimation. Of these, 47 were seen by the primary observer, 42 by the secondary observer and 32 by both observers. Narwhals were seen on 7 of 8 transects and sightings were highly clustered, with the largest number of sightings on Transects 40 and 42 . Narwhal group sizes ranged between 1 and 8 whales. Each transect was 49 to $50 \mathrm{~km}$ in length with a total effort covering $405 \mathrm{~km}$ of the $9514 \mathrm{~km}^{2}$ area (Fig. 1).

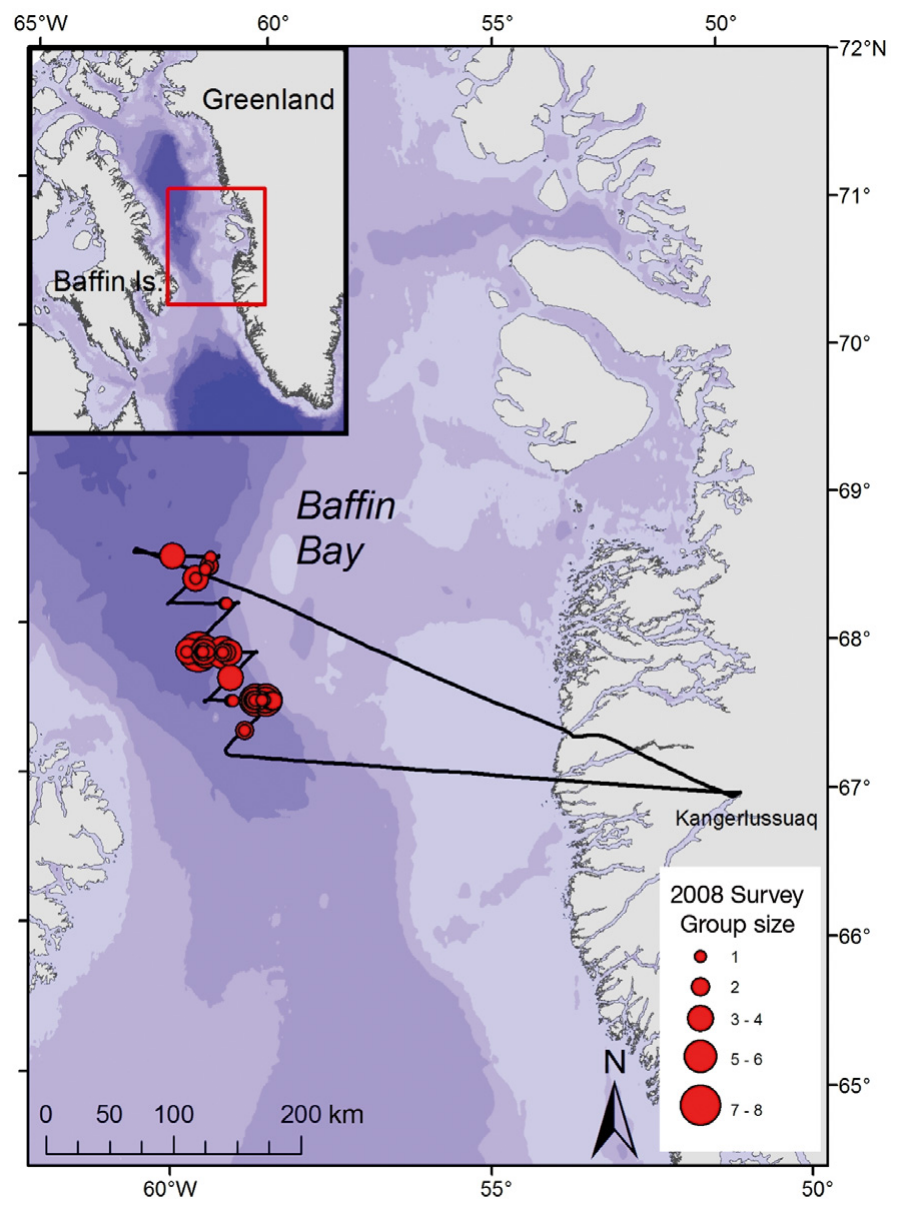

Fig. 1. Monodon monoceros. Survey location and tracklines on 3 April 2008 in the wintering grounds of Baffin Bay. Narwhal sightings are red. Inset shows location of study area between Baffin Island and Greenland

The average probability of detection on the trackline for the primary and secondary observers was 0.72 $(\mathrm{CV}=0.06)$ and the detection for both observers was $0.92(\mathrm{CV}=0.03$, Fig. 2). The abundance of narwhals at the surface, including whales missed by the observers, was estimated to be 3248 whales $(\mathrm{CV}=0.46)$. The estimate was corrected for availability bias (accounting for whales underwater) with a new correction factor of $0.18(\mathrm{CV}=0.04)$ developed by Heide-Jørgensen et al. (2010) for a coastal winter survey of narwhals in West Greenland. The fully corrected estimate, which took into account whales submerged below $2 \mathrm{~m}$ and hence invisible to the observers, was 18044 narwhals (95\% CI, 7623 to 42712 ) (Table 1).

\section{MODIS sea ice habitat estimates}

Within the entire surveyed region, $9556 \mathrm{~km}^{2}$ (152 892 pixels) of sea ice were present in a single $250 \mathrm{~m}$ resolution cloud-free MODIS image (Fig. 3, Table 2). Of this, 


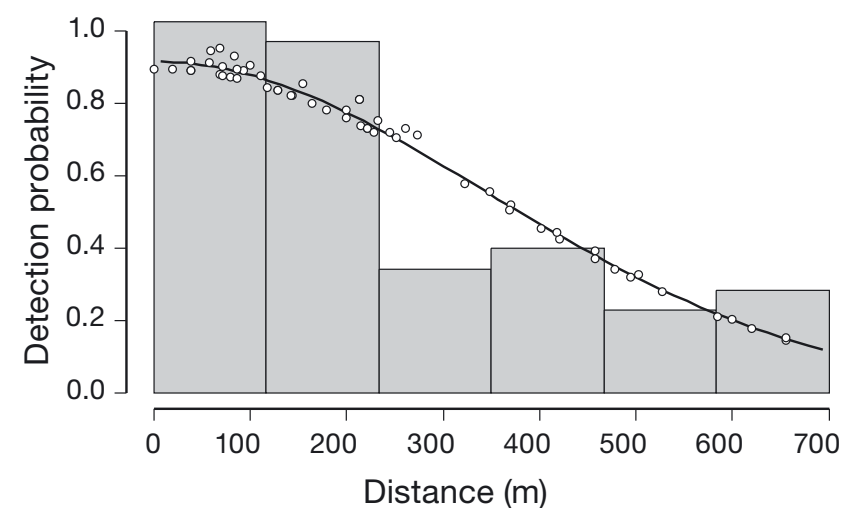

Fig. 2. Monodon monoceros. Detection probability of the pooled detections from rear and front observers in the aircraft using a normal detection function with distance as a continuous variable. The distance of sightings was truncated at $700 \mathrm{~m}$. The points are the probability of detection for each sighting given its perpendicular distance and other covariate values. The line is a smooth function fitted to the points

$233 \mathrm{~km}^{2}$ (3727 pixels) were classified as open water. This amounted to $2.4 \%$ of the surveyed area. Of the other 2 sea ice categories, the new ice was the only other category that could be considered potential narwhal habitat, although this depends on the stage of ice formation. New ice covered $908 \mathrm{~km}^{2}$ (14 521 pixels) of habitat, or $9 \%$ of the surveyed area (Table 2). The remainder of the surveyed area comprised $8415 \mathrm{~km}^{2}$ and was classified as medium or heavy pack ice and not considered potential narwhal habitat (i.e. where whales can surface to breathe). The MODIS image provided complete coverage of the survey trackline.

\section{In situ sea ice habitat estimates}

During the survey over the wintering ground, 1565 digital images were collected along the trackline (Fig. 4). This covered a total area of $71 \mathrm{~km}^{2}$. On average, $196 \pm 53$ (SD) images were taken on each transect; however, the

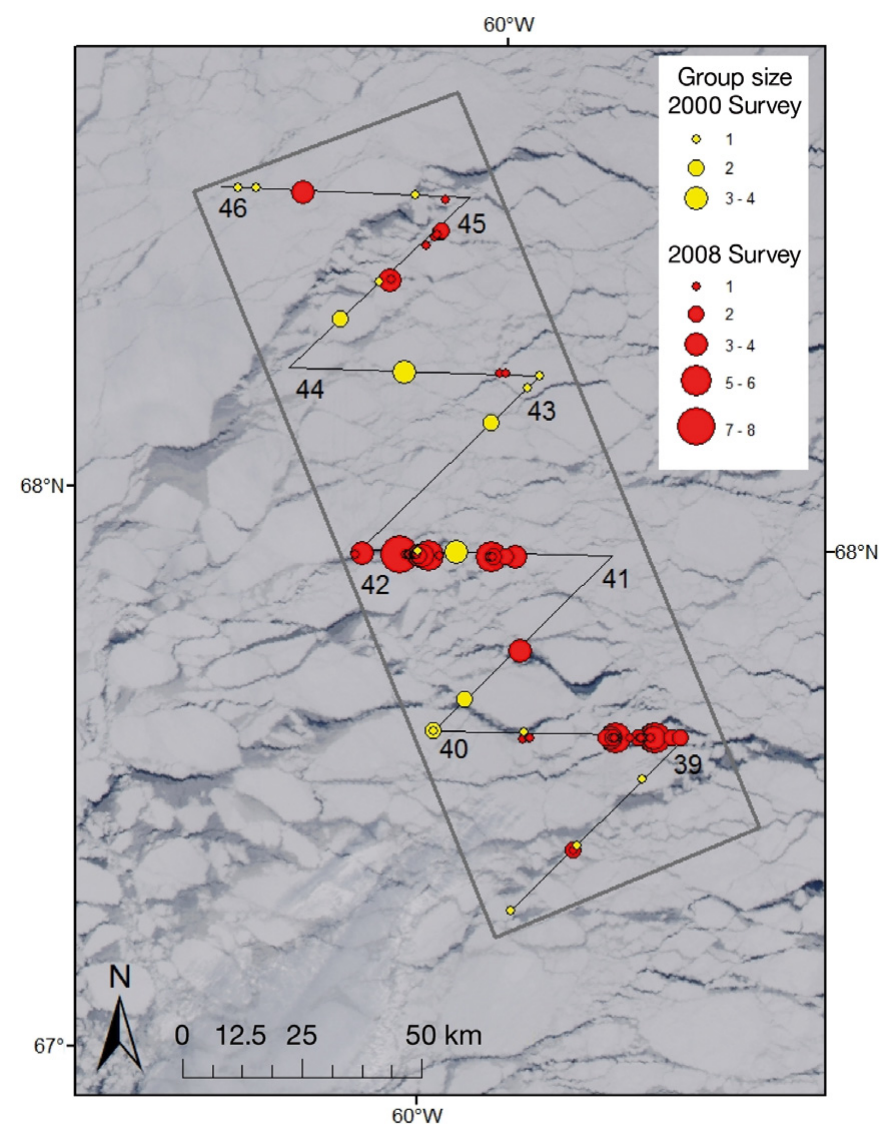

Fig. 3. Monodon monoceros. Close-up of aerial survey sightings of narwhals from the surveys in 2008 (in red) and 2000 (in yellow). MODIS satellite image shown in background was obtained on 3 April 2008 concurrent with the survey of narwhal wintering grounds with cloud-free conditions. Black areas are open water leads. Transect numbers are labeled at the start of each line and the total surveyed area is shown within the box

total number varied (113 to 252) owing to brief unexpected power outages to the camera (Table 3). Each digital image covered an area of $0.045 \mathrm{~km}^{2}$.

Based on all images, an average $( \pm \mathrm{SD})$ of $3.2 \%$ $(15.9 \%)$ open water, $11.1 \%(27.8 \%)$ new ice and $85.7 \%(32 \%)$ heavy ice were calculated in the sur-

Table 1. Monodon monoceros. Estimates of narwhal abundance from an aerial survey over the Baffin Bay pack ice in 2008 and a previous survey conducted in the same area in 2000. The 2008 survey used mark-recapture (MR) sampling (point conditional independence) while estimates from 2000 (Heide-Jørgensen et al. 2002) used traditional distance sampling (2000 estimates modified to the same surveyed area as 2008) (CV in parentheses)

\begin{tabular}{|c|c|c|c|c|c|c|c|c|c|c|}
\hline & $\begin{array}{l}\text { Area } \\
\left(\mathrm{km}^{2}\right)\end{array}$ & Sightings & $\begin{array}{c}\text { Effort } \\
(\mathrm{km})\end{array}$ & $\begin{array}{l}\text { Sighting } \\
\text { rate } \\
\left(\mathrm{n} \mathrm{km}^{-1}\right)\end{array}$ & $\begin{array}{l}\text { Truncation } \\
\text { (m) }\end{array}$ & $\begin{array}{l}\text { Expected } \\
\text { cluster } \\
\text { size }\end{array}$ & $\begin{array}{c}\text { Abundance } \\
\text { of individual } \\
\text { whales }\end{array}$ & $\begin{array}{l}\text { Perception } \\
\text { bias correction } \\
\text { factor }\end{array}$ & $\begin{array}{l}\text { Availability } \\
\text { correction } \\
\text { factor } \\
(0-2 \mathrm{~m})\end{array}$ & $\begin{array}{c}\text { Abundance } \\
\text { corrected for } \\
\text { perception and } \\
\text { availability bias }\end{array}$ \\
\hline 2008 survey & 9514 & $57^{a}$ & 405 & - & $0-700$ & $1.95(0.05)$ & $3248^{\mathrm{b}}(0.46)$ & $0.92(0.03)$ & $0.18(0.04)$ & $18044(0.46)$ \\
\hline 2000 survey & 9514 & 21 & $\sim 400$ & $0.05(0.16)$ & $200-1200$ & $1.4(0.12)$ & $721(0.27)$ & $0.50(0.25)$ & $0.35(0.23)$ & $4121(0.43)$ \\
\hline
\end{tabular}


Table 2. Sea ice habitat classifications from a MODIS image of the surveyed area taken on 3 April 2008

\begin{tabular}{|lrrc|}
\hline Ice type & $\begin{array}{r}\text { No. of } \\
\text { pixels }\end{array}$ & $\begin{array}{r}\text { Area } \\
\left(\mathrm{km}^{2}\right)\end{array}$ & $\begin{array}{c}\text { Fraction } \\
\text { of total }\end{array}$ \\
\hline Open water & 3727 & 233 & 0.024 \\
New ice & 14521 & 908 & 0.095 \\
Medium/heavy pack ice & 134644 & 8415 & 0.881 \\
\hline
\end{tabular}

veyed area. Old/heavy pack ice was relatively consistent across all transects and ranged from 76 to $94 \%$. The amount of open water on each transect was generally $<2 \%$ with the exception of Transect 40 where there was $13 \%$ open water due to one very large sea ice lead. This transect had the largest number of narwhal sightings $(n=23)$, although it should be noted that another transect (Transect 42) also had nearly the exact same number of sightings with only $1.4 \%$ open water (Table 3). The estimate of the sea ice coverage from the continuous video recordings in the entire area was $99.83 \%$.

\section{Probability of sightings with respect to habitat patch composition}

Fifty-two sightings (109 individual whales) could be associated with a unique digital image on the trackline. Of these sightings, 3 were removed because the time difference between the sighting and the nearest digital photo exceeded $3 \mathrm{~s}$. This resulted in 49 sightings of 100 individuals (mean group size $=2.04$ individuals, Table 4). Habitat patch categories with any open
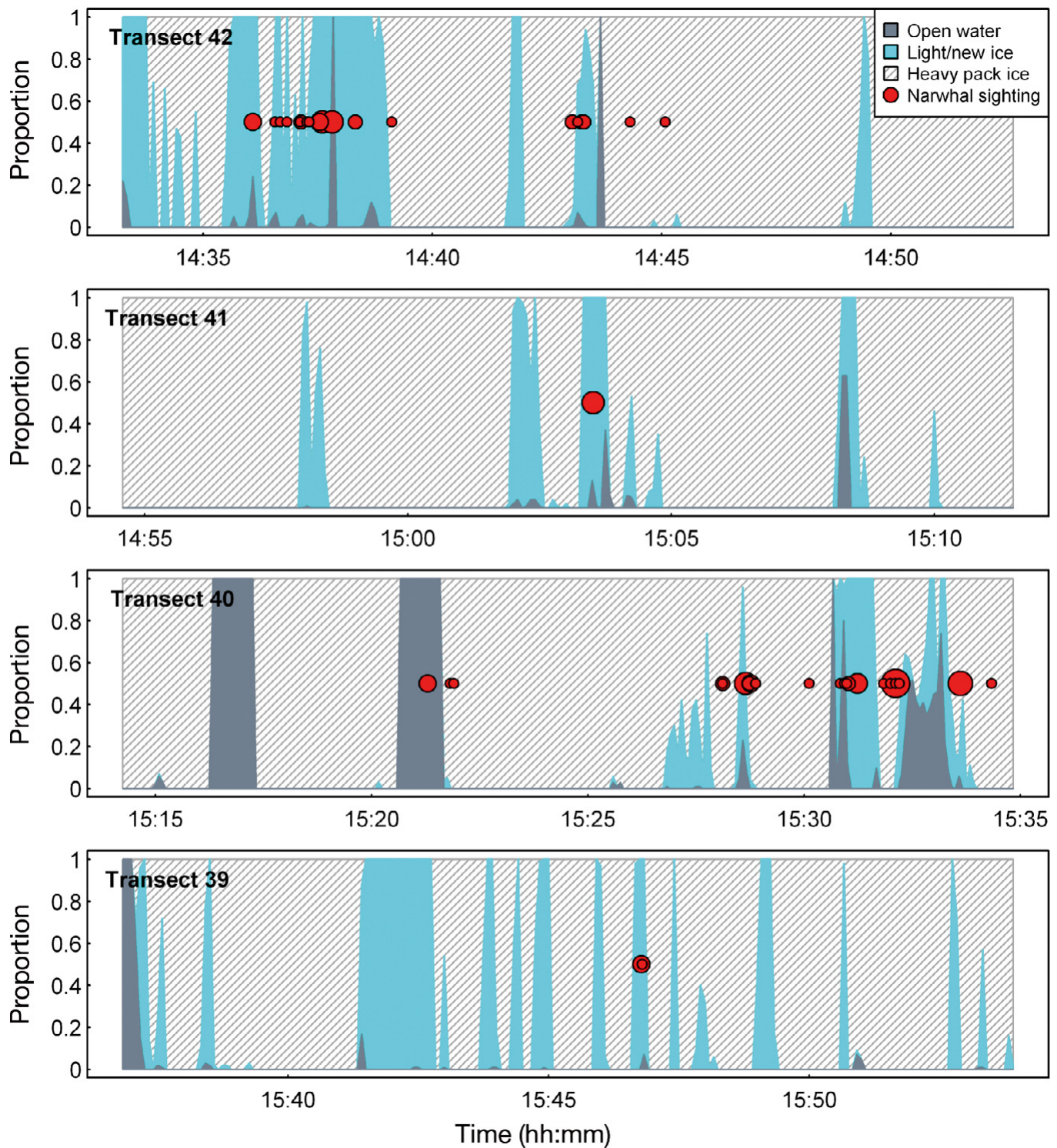

Fig. 4. Monodon monoceros. Habitat proportions of open water, light/new ice and heavy pack ice based on digital images taken every $5 \mathrm{~s}$ along the trackline (data shown for 4 of 8 transects). Narwhal sightings are shown as red symbols and are scaled proportionally according to group size (between 1 and 8 whales) 
Table 3. Fraction of sea ice habitat calculated from digital aerial photography taken along 8 transects during a survey conducted in Baffin Bay on 3 April 2008

\begin{tabular}{|lrrrrrr|}
\hline $\begin{array}{l}\text { Survey } \\
\text { transect }\end{array}$ & $\begin{array}{c}\text { No. of } \\
\text { digital } \\
\text { images }\end{array}$ & $\begin{array}{c}\text { Area } \\
\text { covered } \\
\left(\mathrm{km}^{2}\right)\end{array}$ & $\begin{array}{c}\text { Open } \\
\text { water } \\
\text { fraction }\end{array}$ & $\begin{array}{c}\text { New ice } \\
\text { fraction }\end{array}$ & $\begin{array}{c}\text { Medium/ } \\
\text { heavy pack } \\
\text { ice fraction }\end{array}$ & $\begin{array}{c}\text { No. of } \\
\text { narwhal } \\
\text { sightings }\end{array}$ \\
\hline 39 & 206 & 9.33 & 0.021 & 0.213 & 0.766 & 2 \\
40 & 244 & 11.09 & 0.132 & 0.085 & 0.783 & 23 \\
41 & 204 & 9.24 & 0.010 & 0.096 & 0.893 & 1 \\
42 & 234 & 10.59 & 0.014 & 0.222 & 0.764 & 22 \\
43 & 113 & 5.16 & 0.009 & 0.079 & 0.912 & 0 \\
44 & 194 & 8.78 & 0.002 & 0.066 & 0.932 & 2 \\
45 & 118 & 5.39 & 0.002 & 0.075 & 0.923 & 7 \\
46 & 252 & 11.41 & 0.025 & 0.029 & 0.946 & 3 \\
Sum & 1565 & 70.99 & & & & 60 \\
Average & & & 0.032 & 0.111 & 0.857 & \\
\hline
\end{tabular}

water at all were rare (145 of 1562 images) but accounted for almost half of the total number of narwhal sightings (22 out of 49 sightings). The largest numbers of sightings were made in the vicinity of 2 categories: $100 \%$ heavy/old pack category $(\mathrm{n}=17)$ and $<10 \%$ open water $(\mathrm{n}=15)$. The probability of narwhal sightings near habitats with little $(<10 \%)$ or some (10 to $50 \%$ ) water was significantly higher than the sighting probability near mostly open water habitat (>50\%). The mean probability of a narwhal sighting was 0.031 ; however, this ranged from 0.014 in the vicinity of $100 \%$ heavy ice to 0.192 in the vicinity of 0 to $10 \%$ open water (Table 4). All habitat-specific probabilities varied significantly from the randomization expectation. The average group size was 2.04 with a low amount of variation between categories. Only the 10 to $50 \%$ open water category had a significantly higher mean group size (3.75 individuals, $\mathrm{p}=0.026)$. The heavy ice category accounted for the overwhelming majority of images on the tracklines (1227 of 1562 images).

\section{DISCUSSION}

\section{Abundance of narwhals on the wintering ground}

The fully corrected abundance estimate obtained in this 1-day survey suggests a large abundance of narwhals, approximately 18044 whales $(95 \%$ CI = 7623 to 42712$)$, in the relatively small surveyed area $\left(9500 \mathrm{~km}^{2}\right.$ ). This abundance represents about a quarter of the entire Baffin Bay stock of narwhals (Heide-Jørgensen et al. 2010, Richard et al. 2010). This large number of narwhals was located in an area with $<3 \%$ open water (leads and cracks in the sea ice), as estimated from 3 independent approaches, resulting in an average estimated density of 77 whales $\mathrm{km}^{-2}$ of open water. The narwhal densities detected in this area are unlikely to be representative of densities across the entire Baffin Bay. It is well known that habitat conditions favor this exact area as a preferred narwhal wintering ground. The region has high densities of their preferred prey, Greenland halibut, which are located along the steep slope of the ocean floor in an area with warm bottom temperatures (Laidre et al. 2003, 2004b). The results from this survey reinforce the conclusion from satellite tracking studies (HeideJørgensen et al. 2002, Laidre et al. 2003, Dietz et al. 2008) that central Baffin Bay is an important wintering site for narwhals from both Greenland and Canada.

\section{Previous survey of wintering grounds}

An aerial survey was conducted 8 yr earlier on 25 March 2000 (1 wk earlier than the survey in 2008) and

Table 4. Monodon monoceros. Habitat associations of narwhals based on digital photographic image analysis. The probability of a sighting (P) is the number of sightings (irrespective of group size) divided by the number of associated images. The mean group size is the total number of narwhals seen in the habitat type divided by the number of sightings. Asterisks $\left({ }^{*}\right)$ represent estimates that are significantly different from the mean (bottom row) ${ }^{*} \mathrm{p}<0.05,{ }^{* * *} \mathrm{p}<0.001$

\begin{tabular}{|lrccccc|}
\hline Habitat type & Images & $\begin{array}{c}\text { No of } \\
\text { sightings }\end{array}$ & $\begin{array}{c}\text { Total no. of } \\
\text { narwhals }\end{array}$ & $\begin{array}{c}\text { Probability } \\
\text { of sighting (P) }\end{array}$ & $\begin{array}{c}\text { Mean group size } \\
\text { per sighting }(S)\end{array}$ & $\begin{array}{c}\text { Expected no. of } \\
\text { narwhals per image }\end{array}$ \\
\hline All heavy ice & 1227 & 17 & 34 & $0.014^{* * *}$ & 2.000 & 0.028 \\
Mixed heavy and new ice & 114 & 2 & 6 & 0.018 & 3.000 & 0.053 \\
All new ice & 76 & 8 & 17 & $0.105^{* * *}$ & 2.125 & 0.224 \\
Water $<10 \%$ & 78 & 15 & 23 & $0.192^{* * *}$ & 1.533 & 0.295 \\
$10 \%<$ water $<50 \%$ & 25 & 4 & 15 & $0.160^{*}$ & $3.750^{*}$ & 0.600 \\
Water $\geq 50 \%$ & 42 & 3 & 5 & $0.071^{*}$ & 1.667 & 0.119 \\
Total & 1562 & 49 & 100 & & & \\
Mean & & & & 0.031 & 2.04 & 0.064 \\
\hline
\end{tabular}


covered the same transects with a Twin Otter aircraft flying at a target altitude of $300 \mathrm{~m}$. In the 2000 survey, 20 sightings of narwhals were collected and a fully corrected abundance estimate of 5348 whales $(\mathrm{CV}=0.43)$ was obtained by means of conventional line transect distance sampling. Unfortunately, major technical differences between the survey in 2000 and the one reported here make the 2 estimates nearly impossible to compare. In 2000, flat observation windows, which obstructed the view directly below the aircraft, were used, the areas between 0 and $200 \mathrm{~m}$ from the trackline (Heide-Jørgensen et al. 2002) were excluded and no survey-specific corrections for availability or perception bias were used. The mark-recapture distance sampling estimate reported here is a better estimate of the density and abundance of whales in the wintering ground due to the direct estimation of perception bias and the use of the new correction factor for availability bias. It is noteworthy that in 2000 sightings occurred on every transect with an essentially even distribution, whereas in 2008, $90 \%$ of the sightings were clustered into 2 transects and 1 transect had no sightings. Sea ice coverage in Baffin Bay in 2008 was 15\% less than that during the 2000 survey (Heide-Jørgensen et al. 2002), though it is difficult to assess what influence that may have had on the proportion of the narwhals that wintered in the surveyed area.

\section{Sea ice habitat and narwhal densities}

The estimates of open water, light (or new ice) and heavy sea ice obtained from the MODIS image within the surveyed area (Fig. 3) were in good agreement with the estimates obtained from the digital aerial photographic approach. The MODIS image indicated $2.4 \%$ open water was present in the surveyed area whereas the digital photographic estimate resulted in an average of $3.2 \%$ open water across all 8 transects. Furthermore, the MODIS data and digital photographic data estimated approximately 9.5 and $11.1 \%$ of light (or new) sea ice in the survey area, respectively, and 88.1 and $85.7 \%$ heavy pack ice in the area, respectively.

The proportion of transects covered in sea ice (any concentration) was $99.83 \%$ based on binary estimates from continuous video recordings. This approach is relatively coarse given that it estimates sea ice coverage using a presence-absence method. In regions such as the narwhal wintering grounds, this methodology therefore does not identify the small leads and cracks important for narwhals that are found by means of a higher resolution method such as digital photography or high resolution imagery.

These estimates of open water correspond well with estimates of open water on the wintering grounds re- ported by Laidre \& Heide-Jørgensen (2005b) using the more coarse resolution SSMR/SSMI Bootstrap algorithm satellite sea ice time series (daily $25 \mathrm{~km}$ sea ice concentration) from the National Snow and Ice Data Center. In this study, the narwhal wintering grounds in Baffin Bay were estimated to have $<3 \%$ open water during the point of maximum sea ice cover in March. These results suggest that estimates of open water availability for narwhals is similar using 3 methodologies at 3 spatial scales: (1) estimates from digital photography along the survey transects, (2) estimates from MODIS satellites in the surveyed region and (3) estimates from coarser satellite imagery (SMMR/SMMI) in the entire Baffin Bay wintering area (Laidre \& HeideJørgensen 2005b). These results support the continued use of remote satellite observations for measuring changes in narwhal habitat. This is important for monitoring the pack ice as it is financially and logistically difficult to conduct fine-scale offshore winter surveys at the frequency and spatial extent necessary to quantify changes in habitat.

This study provides the first in situ habitat estimates of open water habitat for narwhals and quantifies the extreme environment in which this species concentrates during winter. The estimated 18000 narwhals in the $\sim 9500 \mathrm{~km}^{2}$ were located in a habitat with $233 \mathrm{~km}^{2}$ of open water (Fig. 2), resulting in a density of $\sim 77$ narwhals $\mathrm{km}^{-2}$ of open water. If one assumes the light pack ice habitat category is also occasionally used by whales (i.e. assuming that whales break ice at all times to breathe), an additional $908 \mathrm{~km}^{2}$ of habitat would be available and estimated densities could be 16 narwhals $\mathrm{km}^{-2}$. This is most certainly an underestimate of narwhal densities, given that the use of the light pack ice category depends on the thickness and age of the new ice. Generally, narwhals only surface in very new ice that is $<2 \mathrm{~cm}$ thick, which means they can use new ice when it is $<24 \mathrm{~h}$ old.

The probability of a narwhal sighting with respect to habitat patch composition was not the highest in areas with the most amount of open water. This is a surprising result, as one might assume that whales would be located in regions with the most open water to avoid sea ice entrapment (Laidre \& Heide-Jørgensen 2005b). Our observation that the probability of a narwhal sighting was significantly higher in regions with $<50 \%$ open water or regions with $<10 \%$ open water suggests that open water is not a habitat feature that narwhals actively select. Rather, narwhals choose optimal foraging habitat in winter, despite dense ice or limited leads and cracks that can lead to sea ice entrapments (see Laidre et al. 2004b, Laidre \& Heide-Jørgensen 2005b, Williams et al. 2010). Jay et al. (2010) reported similar findings for the walrus Odobenus rosmarus divergens, where lack of a clear relationship between walrus displacement and 
sea ice movements suggested that sea ice does not determine the area or extent of walrus foraging nor does it prevent walruses from feeding on local benthic prey.

\section{Narwhal densities and Greenland halibut}

Narwhals feed intensively during winter on Greenland halibut and select their foraging areas based on habitat attributes in which Greenland halibut congregate (Laidre et al. 2004b). The estimated density of narwhals calculated in the 2008 survey would require more than $7 \mathrm{t} \mathrm{km}^{-2}$ of halibut to meet the energetic needs of the whales given a 5 mo residency in Baffin Bay and an estimated daily consumption of 20 to $30 \mathrm{~kg}$ of Greenland halibut (Laidre et al. 2004a). This is about 10 times the density of Greenland halibut (700 kg $\mathrm{km}^{-2}$ ) obtained from offshore fishery surveys in the area (Laidre et al. 2004a). This discrepancy may be due to imprecise estimates of field energetic costs for marine mammals (Acquarone et al. 2006) or because fishery data underestimate the biomass of Greenland halibut available to narwhals. Research vessels sample Greenland halibut biomass at depths <1000 m while deeper narwhal diving depths, which routinely exceed $1500 \mathrm{~m}$, allow whales access to a much larger halibut biomass (Laidre \& Heide-Jørgensen 2005a). Furthermore, an unaccounted for influx of Greenland halibut over the sill from Davis Strait to Baffin Bay could explain a higher halibut consumption level by narwhals than would be accounted for by standing stock estimates.

\section{Summary}

In the case of long-lived and wide-ranging species that inhabit variable environments, the selective pressure of maximizing energy gain and reproductive fitness over a lifetime should lead to the preference for long-term fidelity to foraging regions with high productivity or high energetic return (Bradshaw et al. 2004). In the case of narwhals, decisions on foraging ranges are probably not individual level responses to local prey depletion, but rather are patterns developed early in life to increase the probability of sequestering appropriate food resources in specific areas of Baffin Bay. This strategy would lead to the development of focal foraging areas, or preferred foraging regions during winter.

During the last several decades there have been large-scale changes in the natural environment in the Baffin Bay area. Data obtained from satellites suggest a marked decline in the extent of sea ice in the entire Baffin Bay/Davis Strait region (9 to $11 \%$ per decade decline since 1979; Perovich \& Richter-Menge 2009) and progressively earlier springtime breakup of ice in Baffin Bay (Stirling \& Parkinson 2006). Ocean temperatures in West Greenland have warmed since the mid1990s at all depths (Zweng \& Münchow 2006), with an especially prominent increase in temperature beginning in 2000 (Laidre et al. 2009, 2010). This is caused by an increase in the inflow from the relatively warm Irminger Current into South and West Greenland (Myers et al. 2007). In light of these recent changes, it is necessary to regularly survey the offshore occurrence of narwhals and detect changes in density and abundance while simultaneously monitoring longerterm changes in sea ice trends. This study provides several pieces of this baseline information for narwhals, which are among the most vulnerable cetaceans in the Arctic to the effects of climate change (Laidre et al. 2008).

Acknowledgements. This study was funded by a NASA ROSES grant (Grant no. NNX08AF71G) to K.L. and M.P.H.J. and by the Greenland Institute of Natural Resources. Thanks to the observers, who flew on the survey in 2008, Air Greenland for providing skilled pilots, and $\mathrm{H}$. Stern for providing the MODIS sea ice image. J. Coyle, T. Broomfield and M. Logsdon provided assistance with GIS sea ice digitizing and E. Gurarie provided expertise with habitat analyses. The Vetlesen Foundation provided funding for the survey recording equipment. Three anonymous reviewers improved the paper.

\section{LITERATURE CITED}

> Acquarone M, Born EW, Speakman JR (2006) Field metabolic rates of walrus (Odobenus rosmarus) measured by the doubly-labelled water method. Aquat Mamm 32:363-369

Borchers DL, Laake JL, Southwell C, Paxton CGM (2006) Accommodating unmodelled heterogeneity in doubleobserver distance sampling surveys. Biometrics 62:372-378

Bradshaw CJA, Hindell MA, Sumner MD, Michael KJ (2004) Loyalty pays: potential life history consequences of fidelity to marine foraging regions by southern elephant seals. Anim Behav 68:1349-1360

Dietz R, Heide-Jørgensen MP, Richard P, Orr J, Laidre KL, Schmidt HC (2008) Movements of narwhals (Monodon monoceros) from Admiralty Inlet monitored by satellite telemetry. Polar Biol 31:1295-1306

Heide-Jørgensen MP, Dietz R, Laidre KL, Richard P (2002) Autumn movements, home range and winter density of narwhals (Monodon monoceros) from Tremblay Sound, Baffin Island. Polar Biol 25:331-341

> Heide-Jørgensen MP, Dietz R, Laidre KL, Richard P, Orr J, Schmidt HC (2003) The migratory habits of narwhals. Can J Zool 81:1298-1305

> Heide-Jørgensen MP, Laidre KL, Burt ML, Borchers DL and others (2010) Abundance of narwhals (Monodon monoceros) on the hunting grounds in Greenland. J Mammal 91:1135-1151

Innes S, Heide-Jørgensen MP, Laake JL, Laidre KL, Cleator HJ, Richard PR, Stewart REA (2002) Surveys of belugas and narwhals in the Canadian high Arctic in 1996. NAMMCO Sci Publ 4:147-190 
Jay CV, Udevitz MS, Kwok R, Fischbach AS, Douglas DC (2010) Divergent movements of walrus and sea ice in the northern Bering Sea. Mar Ecol Prog Ser 407:293-302

Laake JL, Borchers DL (2004) Methods for incomplete detection at distance zero. In: Buckland ST, Anderson DR, Burnham KP, Laake JL, Borchers DL, Thomas L (eds) Advanced distance sampling. Oxford University Press, Oxford

Laidre KL, Heide-Jørgensen MP (2005a) Arctic sea ice trends and narwhal vulnerability. Biol Conserv 121:509-517

Laidre KL, Heide-Jørgensen MP (2005b) Winter feeding intensity of narwhals. Mar Mamm Sci 21:45-57

> Laidre KL, Heide-Jørgensen MP, Dietz R, Hobbs RC, Jørgensen OA (2003) Deep-diving by narwhals Monodon monoceros: differences in foraging behavior between wintering areas? Mar Ecol Prog Ser 261:269-281

Laidre KL, Heide-Jørgensen MP, Jørgensen OA, Treble M (2004a) Deep-ocean predation by a high Arctic cetacean. ICES J Mar Sci 61:430-440

Laidre KL, Heide-Jørgensen MP, Logsdon ML, Hobbs RC and others (2004b) Seasonal habitat associations of narwhals in the high Arctic. Mar Biol 145:821-831

Laidre KL, Stirling I, Lowry LF, Wiig Ø, Heide-Jørgensen MP, Ferguson SH (2008) Quantifying the sensitivity of Arctic marine mammals to climate-induced habitat change. Ecol Appl 18:S97-S125

Laidre KL, Heagerty $\mathrm{P}$, Heide-Jørgensen MP, Witting L, Simon M (2009) Sexual segregation of common minke whales (Balaenoptera acutorostrata) and sex ratio of catches in Greenland. ICES J Mar Sci 66:2253-2266

Laidre KL, Heide-Jørgensen MP, Ermold W, Steele M (2010) Narwhals document continued warming of Baffin Bay.

Editorial responsibility: Hans Heinrich Janssen, Oldendorf/Luhe, Germany
J Geophys Res 115:C10049 doi:10.1029/2009JC005820

Lerczak JA, Hobbs RC (1998a) Calculating sighting distances from angular readings during shipboard, aerial, and shorebased marine mammal surveys. Mar Mamm Sci 14:590-598

Lerczak JA, Hobbs RC (1998b) Errata. Mar Mamm Sci 14:903

Myers PG, Kulan N, Ribergaard MH (2007) Irminger Water variability in the West Greenland Current. Geophys Res Lett 34:L17601 doi:10.1029/2007GL030419

Perovich DK, Richter-Menge JA (2009) Loss of ice in the Arctic. Annu Rev Mar Sci 1:417-441

R Development Core Team (2009) R: a language and environment for statistical computing. R Foundation for Statistical Computing, Vienna. Available at: www.r-project.org/

Richard PR, Laake JL, Hobbs RC, Heide-Jørgensen MP, Asselin N, Cleator H (2010) Baffin Bay narwhal population distribution and numbers: aerial surveys in the Canadian High Arctic, 2002-2004. Arctic 63:85-99

Stirling I, Parkinson CL (2006) Possible effects of climate warming on selected populations of polar bears (Ursus maritimus) in the Canadian Arctic. Arctic 59:261-275

Thomas L, Laake JL, Rexstad E, Strindberg S and others (2009) Distance 6.0. Release 2. Research Unit for Wildlife Population Assessment, University of St. Andrews. Available at: www.ruwpa.st-and.ac.uk/distance/

Williams TM, Noren SR, Glenn M (2010) Extreme physiological adaptations as predictors of climate-change sensitivity in the narwhal, Monodon monoceros. Mar Mamm Sci (in press) doi:10.1111/j.1748-7692.2010.00408.x

Zweng MM, Münchow A (2006) Warming and freshening of Baffin Bay, 1916-2003. J Geophys Res, 111:C07016 doi:10. 1029/2005JC003093

Submitted: July 13, 2010; Accepted: November 17, 2010

Proofs received from author(s): February 1, 2011 